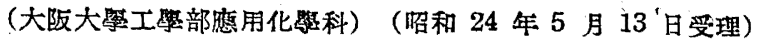

\title{
（21）生コム高溫分解に關する研究（第5 報）
}

$$
\text { イソデカンの合成 }
$$

$$
\text { 戸 倉 仁一郎 }
$$

生ゴム分解に体てイッブレンを得ることは周知の如くである か，著者は分解を比較的高溫に於て行う事に依て可及的にイップ レンを收量良く得ることを試みだ122。この際生成するゴムタール

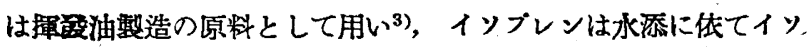
ベンタン (II)を得る。或恃共䡉二重結合の一方のみを水添して. イソフミレン(III) とし, ついで重合してイソデャン(IV), これ を水添してイソデカン (V)を合成することができる。イソベンタ ン,イソデカンは何れもオクタン價高く，配合然料として有用で ある。<smiles>C=C(C)C=CCCCCC(C)C(C)C</smiles>

\section{貫 驗 の 部}

原料イソブレン 生ゴムを $600^{\circ} \mathrm{C}$ で管狀䀯で分解して得だも の, 涨點 32 38 $38^{\circ} \mathrm{C} d_{4}^{10}=0.679 n_{1}^{10}=1.4151$ 少量のイソアミレ

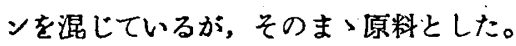

分 析: イソブレン, イソフミンン, イソペンタン 3 成分混合 物の分析は，無水マレ・ンン酸及び $90 \%$ 硫酸に吸收せしめて，別 々に定量した。その詳細は前報りの如くである。

接野水素添加 觸媒はニッケルを用い, Adkins 法4)で珪藻士た 泌着させたものを, 豆粒大の輕石に染布した。輕石 3 に對して, Adkins 觸媒 1 の重量比である。 $40 \mathrm{~g}(106 \mathrm{cc})$ の觸媒は全唱とし

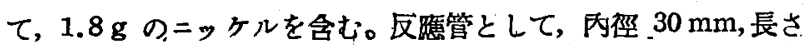
$1.2 \mathrm{~m}$ の磁製管を用いた。觸媒は使用前に水素氣流中 1 時間 $350^{\circ} \mathrm{C}$ で還元した。

インペンタン(II) 觸媒 $80 \mathrm{~g}$ を反應管につめ, イシプレン $68 \mathrm{~g}$, 水素 $56 l$ を $150^{\circ} \mathrm{C} て ゙ 4$ 時間かかつて, 通過せしめた。生成物を 內䄇 $2 \mathrm{~cm}$, 長さ $1 \mathrm{~m}$ のラッシッ七分箇管で分溜し, 沸點 $27 \sim 29^{\circ} \mathrm{C}$ をとる。收量 $64 \mathrm{~g}(94.1 \%), d_{4}^{15}=0.620, n_{D}^{15}=1.3585$ ，分子量 73.2 (v. Meyer 泆), 理論值 $\mathrm{C}_{5} \mathrm{H}_{12}$ 72.1, 單味オクタン價 91 。 インアミレン(III) 反锶管の前半には,小口俓のガラスンング をつめ, 後牛に觸媒 $40 \mathrm{~g}$ をつめる。反㮣溫度 $150^{\circ} \mathrm{C}$, イソブレン
$68 \mathrm{~g}$, 水素 $56 l$, 反然時間 4 時間で, $67 \mathrm{~g}$ の液體が得られる。こ り組成はイソプレン $14.5 \%$, イッアミレン $83.3 \%$,イッペンタン $2.2 \%$ で,イソアミレンは收慗 $81.8 \%$ で得られる。同し佟件で, 更に水 $180 \mathrm{~g}$ を加えつつ, 水素添加を行わせると，イッアミレシ の收䋱は $83.7 \%$ となる。

生成物を $1 \mathrm{~m}$ のラッシッ七管で分溜すると，大部分が $35 \sim 44^{\circ} \mathrm{C}$ の溜分であつて，イッフミレンの3 異性䯣の中，主としてトッメ チルムチレン（(III) の形）であることが分る。

生成物は, $d_{4}^{10}=0.663, n_{D}^{10}=1.3872$, イソプレン, イソベンタ ンを含んでいる。この混合物を除去せずに，このまま重合に用い た。

重合(イソデセン:（IV）の合成） $-15^{\circ} \mathrm{C}$ に冷した 70\% 硫酸

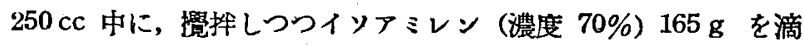
下する。このときや，發抄する。發熱やむと次第に溫度を上げ， $50^{\circ} \mathrm{C}$ に到らしめる。約 20 分この溫度に保つた後, 室溫で放置す る。上眉には暗紅色の重合油が分れる。これを分ち10\% $\mathrm{NaOH}$ 水溶液で洗い，更に水洗を行い，芒硝にて乾燥の後，ウィドマ一


溜分 $83.2 \mathrm{~g}$ を得る。佾 $160^{\circ} \mathrm{C}$ 以上のものも $6.6 \mathrm{~g}$ 得られる。

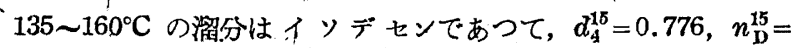

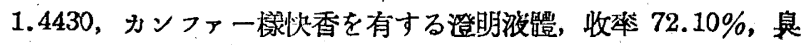
素潧 120.00, 理論值 $\mathrm{C}_{10} \mathrm{H}_{20} \mathrm{~F}_{1}, 114.17$ ，分子量 139.5 (ベンゾー 几承點降下), 理論値 $\mathrm{C}_{10} \mathrm{H}_{20}$ 140.2。

インデカン (V) 䪅媒 $40 \mathrm{~g}$ を反應管につめ， $180^{\circ} \mathrm{C}$ で，イソテ 七ン $140 \mathrm{~g}$ を水素の過剩と 3 時間かかつて通過せしめる。生成物

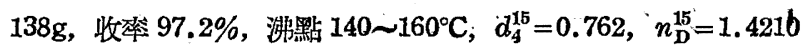
臭素價 0.21 , カンファー栐の香氣を有する。分子量 143.8 , 理論 值 $\mathrm{C}_{10} \mathrm{H}_{22}$ 142.2, 單味オクタン價 95 。

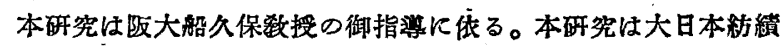
大堤化聚工場に於て行われたるのである。深謝の表をる。

\section{一引用交椐-}

1) F倉 : 工化, 51, 30(1948).

2) B. Bownstra and G. von Amerongen : Ind. E'ng. Chem., 41, 161 (1949).

3)' 日本特锌, 169146(1944).

4) Adkins : J.Am. Chem. Soc., 54, 1651(1932). 